\title{
BREVE ESTUDO DE UMA PERSPECTIVA DE EDUCAÇÃO MEDIEVAL ${ }^{1}$
}

\section{BRIEF STUDY FROM A MEDIEVAL PERSPECTIVE OF EDUCATION}

\author{
Rosana Silva de Moura*
}

\begin{abstract}
Resumo: A época medieval não está fora da busca pela questão da finalidade do ensino. Neste ensaio analiso aspectos da filosofia da educação medieval a partir das contribuições de Santo Agostinho e Tomás de Aquino sobre o ensino. Especialmente através do método da Escolástica, o filósofo interroga sua época sobre a verdade do ensino: Somente Deus pode ser chamado de mestre, porque ensina, ou ao homem também é possível atribuir-se essa tarefa? No texto do século XIII, Aquino analisa o processo pelo qual o aluno aprende nos oferecendo o elemento da descoberta como o momento individual do processo de aprendizagem.
\end{abstract}

Palavras-chave: Filosofia da Educação Medieval. Santo Agostinho. Tomás de Aquino. Ensino. Descoberta.

\begin{abstract}
The medieval time is not out of the search for the education purpose. In this assay I analyze the medieval education philosophy aspects from Saint Augustine and Thomas Aquinas' teaching contributions. Especially through the Scholasticism method the philosopher interrogates their time about the truth of education: May only God be called master because he teaches or it is also possible to attribute this task to men? In the thirteenth century text Aquino analyzes the process by which students learn giving us the element of the discovery as an individual learning moment.
\end{abstract}

Keywords: Medieval Education Philosophy. Saint Augustine. Thomas Aquinas. Teaching. Discovery.

* Professora no Programa de Pós-Graduação em Educação da Universidade Federal de Santa Catarina (UFSC). Coordena pesquisas em "Hermenêuticas da Cultura, mundo e educação”. E-mail: rosanasilvademoura@gmail.com 
Neste breve estudo analiso elementos das filosofias da educação de Santo Agostinho (354-430) e Tomás de Aquino (1225-1274), pensadores situados no horizonte da educação medieval. Não abro mão de um diálogo entre filosofia e história na elaboração das filosofias da educação destes pensadores, o que justifica a interpretação do espírito do tempo (Zeitgeist) medieval. Mesmo assim, não tratarei do vasto universo de suas filosofias. Quero dizer com isto que não problematizarei aqui questões que vinculam, por exemplo, a filosofia de Aquino com Averróis, pela conhecida convergência do pensamento de ambos em relação ao aristotelismo, ou de questões que interligam a educação cristã ao islã, algo que ficará em aberto, podendo ser tratado em outra ocasião. Delimitando, meu objeto é a filosofia da educação expressa na interpretação da ideia de ensino que o autor nos oferece.

Por isso, inicialmente destaco que o propósito de fazer ponte entre filosofia, educação e história encontra sua razão de ser na filosofia da educação, que se ocupa particularmente de questões que fertilizam a formação humana tendo em vista o ser no tempo. Guardadas as especificidades inerentes a cada um desses campos, tanto a filosofia e a educação, assim como a história, têm em seus horizontes de investigação a questão da produção do conhecimento como modo peculiar do humano, refletindo sua formação. A conexão entre esses horizontes revela certa legitimidade da filosofia da educação indicando um télos para a educação subjacente a todo movimento que lhe é concernente. Esta parece ser uma questão elementar para a educação: sua motivação e finalidade. Mas também pode ser uma questão para a filosofia, pois em qualquer época o homem se depara com esta interrogação, especialmente quando se inquieta com a produtividade de sentidos em sua formação intelectual; quando se depara com o modus operandi do ensino, seu como, sua linguagem. A época medieval não está fora da busca pela questão da finalidade do ensino, ou seja, também ali se encontra um télos, assim como na Antiguidade Clássica e na modernidade.

\section{O ESPÍRITO DO TEMPO E O HOMO HIERARQUICUS}

Como sabemos a Idade Média foi um tempo de longa duração altamente rico em função de seus contrastes e ambivalências. ${ }^{2}$ Além disso, cabe dizer que mesmo não sendo propósito adentrar em especificidades históricas concernentes à medievalística é importante deixar claro que estudos já ultrapassam o limite de uma tradução dos tempos medievais como sendo de um quadro de homogeneidade cultural, dadas as intensas mediações presentes na Europa medieval entre cristãos, judeus e muçulmanos como podemos verificar na própria formação intelectual da época que guarda suas peculiaridades nas nomenclaturas Alta e Baixa. ${ }^{3}$ De modo amplo, aquela produzindo o que 
ficou conhecido como Patrística e esta como Escolástica. Para falar da época medieval, a belíssima metáfora de Johan Huizinga elegida para o título de sua obra, clássica, cuja primeira edição data de 1919, já sintetiza o período histórico como uma transformação - o outono nem de longe é aquilo que parece, folhas mortas, mas sim um momento no qual as coisas estão se fazendo, se transformando. Um momento próprio que por ser assim, não é mais o anterior tampouco o subsequente. Vale a pena determo-nos nas palavras inspiradoras do historiador para uma interpretação daqueles tempos:

Assim como o contraste entre o verão e o inverno era mais severo do que para nós, também o era o contraste entre a luz e a escuridão, o silêncio e o ruído [...] O contraste contínuo e as formas simbólicas com as quais tudo se imprimia na alma conferiam à vida cotidiana uma excitação e um poder de sugestão que se manifestavam nos ânimos instáveis de emotividade tosca, crueldade extrema e ternura íntima entre os quais se movia a vida urbana medieval. ${ }^{4}$

Tal ambivalência parece refletir um viés antropológico. Assim, segundo Cambi, encontramos nesta época a marca antropológica de um Homo hierarquicus conduzido por uma estrutura permeada da Igreja formadora da "consciência cristã". ${ }^{5}$ No entanto há que se ressalvar o sentido de uma autoridade alimentada na tradição, ultrapassando certa rigidez posta imediatamente na imagem daquela instituição. Convém destacar que a ideia de autoridade também remete a um conteúdo de sabedoria, especialmente contrário a uma orientação arbitrária, oriunda de uma irracionalidade conforme sugere Hans-Georg Gadamer:

Todavia, não é isso a essência da autoridade. Na verdade, a autoridade é, em primeiro lugar, um atributo de pessoas. Mas a autoridade das pessoas não tem seu fundamento último num ato de submissão e de abdicação da razão, mas num ato de reconhecimento e de conhecimento: reconhece-se que o outro está acima de nós em juízo e perspectiva e que, por consequência, seu juízo precede, ou seja, tem primazia em relação ao nosso próprio. Junto a isso dá-se que a autoridade não se outorga, adquire-se, e tem de ser adquirida se a ela se quer apelar. Repousa sobre o conhecimento e, portanto, sobre uma ação da própria razão que, tornando-se consciente de seus próprios limites, atribui a outro a perspectiva mais acertada [...] Na realidade, autoridade não tem nada a ver com obediência, mas com conhecimento. ${ }^{6}$ 
Por isso reconhecemos autoridade de quem conhece (incluindo-se também o texto). E, para acentuarmos o pertencimento do termo à tradição, cabe lembrar que já em Aristóteles aos mestres é conferida autoridade porque "possuem a teoria" (algo da ordem da vida contemplativa, conforme veremos adiante). Esta orientação acompanha a figura de autoridade de quem carrega o conhecimento, mantendo a estrutura da teologia cristã. Percebemos que a instituição eclesiástica reunia de modo ímpar as forças intelectuais da época e delas se ocupava. Como se dava esta relação entre Igreja e escola na Idade Média?

\section{ALGUNS ASPECTOS DA ESCOLA NA IDADE MÉDIA}

Também a escola, como nós a conhecemos, é um produto da Idade Média. A sua estrutura ligada à presença de um professor que ensina a muitos alunos de diversas procedências e que deve responder pela sua atividade à Igreja ou a outro poder (seja local ou não); suas práticas ligadas à lectio e aos auctores, à discussão, ao exercício, ao comentário, à arguição etc.; as suas práxis disciplinares (prêmios e castigos) e monásticas e nas catedrais e sobretudo nas universidades. Vêm de lá também alguns conteúdos culturais da escola moderna e até mesmo contemporânea: o papel do latim, o ensino gramatical e retórico da língua; a imagem da filosofia, como lógica e metafísica. ${ }^{8}$

Através do estudo de Cambi, curiosamente percebemos que esta instituição moderna tem raízes medievais. A partir deste entendimento percebemos o projeto de expansão e penetração da Igreja que trata de se apresentar ao mundo imbuída de uma função pedagógica. Logo, encontramos a importância da presença de sua escola:

A Igreja foi o "palco fixo" por trás do qual se moveu toda a história da Idade Média e um dos motores do seu inquieto desenvolvimento [...] A Europa, de fato nasceu cristã e foi nutrida de espírito cristão, de modo a colocá-lo no centro de todas as suas manifestações, sobretudo no âmbito cultural. Caso exemplar é o da educação, que se desenvolve em estreita simbiose com a Igreja, com a fé cristã e com as instituições eclesiásticas que [...] são as únicas delegadas (com as corporações no plano profissional) a educar, a formar, a conformar. Da Igreja partem os modelos educativos e as práticas de formação [...]. ${ }^{9}$ 
Logo, é perceptível que tal formação demandasse a constituição de um corpus que lhe sustentasse, daí a iniciativa da formação clerical e, sob esta orientação, "o êxito da escola deve-se, em parte, ao papel da Igreja". ${ }^{10}$

Colette Beaune, medievalista francesa, tece com mais detalhes as tramas das primeiras escolas no Ocidente nos apresentando o que considero uma cartografia das escolas nos séculos XIV e XV na França, Itália e Inglaterra seja no âmbito laico ou no religioso. No primeiro caso, para atender à nova configuração emergente de cidades europeias, como no caso da Itália (Milão e Veneza), com formação para a demanda mercantil e notarial e, no segundo caso, para dar conta da formação religiosa demandada pela Igreja, especialmente na França e Inglaterra. Beaune esclarece com isto que a expansão da escola não aconteceu para alavancar um ou outro setor da sociedade do Baixo medievo ocidental, mas para dar vazão a essas diferentes conotações para o ensino e, mesmo expandindo-se de modo ainda pouco organizado, a escola desde cedo conferia capital social. Basicamente as escolas são mais para meninos que para meninas, mais para citadinos que rurais mais de caráter privado que público. O tempo médio de escolarização é de seis meses a cinco anos. A média etária dos frequentadores da escola é de 7 a 14 anos. Em suma, para esta autora, "ter frequentado a escola constitui uma prova de honradez, útil para conseguir um bom casamento, tornar-se administrador dos bens da paróquia ou magistrado municipal". ${ }^{11}$

Como podemos perceber, a Igreja ergue-se como uma estrutura a partir da qual se produzia também uma inserção social que acabou promovendo, significativamente, um destaque para a escola como lugar de ascensão social. Mas não é só isto. Como vimos, além de uma demanda pela formação clerical havia também uma demanda pela especialização dos ofícios que a cidades apresentavam. Ou seja, a escola foi surgindo pari passu com os interesses da época, fossem eles de ordem laica ou religiosa.

\section{UNIVERSIDADES, INTELECTUAIS E ESCOLÁSTICA (MÉTODO E CURRÍCULO)}

Segundo Jacques Le Goff, assim como Alain De Libera, a Idade Média dos séculos XII e XIII viu florescer uma das experiências humanas mais marcantes e decisivas não só para sua época, mas especialmente para o racionalismo ocidental dos tempos posteriores: a criação e assunção da universidade como lugar maior do espírito humano na identidade do intelectual, dado a pensar o mundo para além do prosaico do cotidiano. ${ }^{12}$ No entanto, conforme sinalizamos anteriormente, cabe lembrar que a heterogeneidade cultural na Idade Média estendeu-se ao universo das Universidades, pois 
[...] séculos antes da obra de Aristóteles ser discutida na Paris do século XIII, muçulmanos, cristãos e judeus já trabalhavam em conjunto na tradução e interpretação de textos aristotélicos na escola de tradução de Bagdá (séculos VII-IX d. C.). A mesma colaboração é documentada na escola de tradução de Toledo (século XII-XIII), a qual traduziu os trabalhos do árabe para o latim. A necessidade de utilizar intelectuais de diferentes idiomas no trabalho de tradução formou uma comunidade de tradutores e comentadores multicultural ao longo destes quatrocentos anos na área mediterrânica. ${ }^{13}$

Conforme a autora sinaliza, encontra-se uma presença significativa daquelas culturas precedendo os trabalhos que serão desenvolvidos nas Universidades europeias (inclusive porque, como sabemos, desde o século X o Oriente já se adiantara na experiência universitária).

Bittar também apresenta, à luz de Etienne Gilson, um estudo sobre esta marca histórica fundamental desvelando a importância da passagem dos árabes na história da filosofia medieval cristã. Neste ponto vale uma breve incursão no tema. Segundo o estudo de Bittar, aqui exposto de modo muito resumido, a trajetória da cultura grega antiga não aconteceu em relação direta e imediata para a filosofia medieval cristã. Com o fechamento das escolas atenienses por Justiniano, no século VI de nossa era, "[...] as abadias se tornaram o primeiro reduto de conservação e preservação de um patrimônio intelectual e cultural [...]"14, ou seja, dos textos clássicos helenistas. Em consonância a este fato, sírios, árabes e judeus (estes dois últimos na Espanha) compõem a trajetória da preservação deste patrimônio (e, neste cenário, o autor destaca especialmente as figuras de Avicena, Averróis e Maimônedes, na Espanha). Bittar chega a referir o hibridismo cultural presente em Toledo como referência emblemática da complexidade que foi a formação cultural e intelectual na Idade Média e, com isso, salvaguardar o próprio hibridismo do horizonte filosófico da época. Logo, a formação da intelectualidade cristã ocidental foi possível em função deste trajeto via Oriente, que ironicamente se deu em solo espanhol. Isto equivale a dizer que o Aristóteles que nos chegou tem o matiz de seu maior comentador, Averróis, muçulmano nascido em Córdoba (1126). Isto significa que, além de termos em conta uma escolástica na pena de Aquino, também precisamos ter em mente a releitura da obra de Aristóteles a partir daquela mediação muçulmana.

Esta compreensão do hibridismo que desentranha o processo de formação da Idade Média enquanto um tempo de territórios fixos entendidos como Ocidente e Oriente, também é analisado por Alain De Libera e se traduz no que o historiador da filosofia chama "translação cultural", um movimento cultural e filosófico de trânsito da e pela cultura bizantina, uma "filosofia pagã", 
como ele diz. Esta perspectiva da participação do Oriente, tão pouco explorada na filosofia da educação, encontra-se encoberta, de fato, pelo processo de ocidentalização das ideias. Nesse sentido, a história da filosofia apresentada pelo autor nos lembra que há uma intrincada rede de formação daquilo que comumente denominamos pensamento ocidental. Nesta trama,

[...] nem todos os caminhos saem de Roma, nem mesmo de Atenas e, tampouco, todos levam a Paris. Há várias translationes studiorum nos confins da Antiguidade e da Idade Média: uma é feita de Atenas para Pérsia e da Pérsia para Harran (a não ser que essas duas translações formem uma só); outras se fazem de Alexandria para os mosteiros sírios dos séculos VII e VIII; um terceiro movimento vai da cultura siríaca para a cultura árabe, de Alexandria a Bagdad. Esses movimentos ocupam toda a Alta Idade Média [...] Nessa mesma época, o Ocidente cristão é filosoficamente estéril. Só desperta de seu longo sono com uma nova translatio, que vem de Bagdad para Córdoba e, daí para Toledo, isto é: do Oriente muçulmano para o Ocidente muçulmano e, de lá, para o Ocidente cristão. ${ }^{15}$

No que se refere ao elemento cristão (que desembocará na instituição da escolástica), a própria estética (expressa, por exemplo, na arquitetura da igreja medieval) dá conta de sinalizar o tanto de ascese religiosa presente no espírito daquele tempo:

Havia um único e inconfundível som que vencia sempre o clamor da vida agitada e que, por mais difuso que soasse, por um momento elevava tudo a uma esfera de ordem: o dobrar dos sinos. Na vida cotidiana, os sinos eram como espíritos protetores cujas vozes familiares ora anunciavam o luto, a alegria, a paz ou a desordem; ora conclamavam, ora advertiam. ${ }^{16}$

Segundo Gombrich, no século XII, no Ocidente, encontramos uma "igreja militante" que se impõe sobremaneira no século seguinte, com as catedrais sendo "igrejas próprias dos bispos (cathedra=trono episcopal)". Assim, o século XIII foi o século das catedrais, e a "[...] a França era o mais rico e o mais importante país da Europa. A Universidade de Paris era o centro intelectual do mundo ocidental". ${ }^{17}$ Jacques Le Goff chega a referir-se às catedrais como uma das maravilhas da Idade Média, não só pela grandiosidade arquitetônica que ela apresenta ao Ocidente, mas também pela riqueza simbólica que ela oferece às comunidades onde se instala. ${ }^{18}$ 
Sob este influxo, a Europa ocidental também experimentou o surgimento e a expansão das universidades entre os séculos XII e XIII, logo se encontrando impregnada de um "aristotelismo cristão". ${ }^{19}$

Em outras palavras,

podemos considerar que tanto a criação das universidades quanto a das ordens religiosas reflete as grandes transformações pelas quais passa o mundo europeu nesse período. É significativo, portanto, que se deem praticamente no mesmo momento e sejam aprovadas pelo mesmo papa, Inocêncio III. As universidades surgem em consequência do grande desenvolvimento das escolas ligadas às abadias e catedrais no processo iniciado desde o período carolíngio. Com o crescimento dos núcleos urbanos e o enriquecimento da sociedade, a demanda por educação aumenta progressivamente, tanto no sentido eclesiástico, visando à formação de uma elite para combater os hereges, quanto no leigo e civil, relacionada às necessidades do governo e da administração pública. As primeiras universidades resultam, na verdade, da aplicação do modelo das ligas ou corporações de ofício no campo da educação, reunindo por um lado mestres e por outros estudantes, provenientes de diferentes regiões da Europa em uma determinada escola ou cidade..$^{20}$

Ao mesmo tempo, Alain De Libera acentua a decisiva importância das universidades medievais ocidentais na definição da identidade intelectual porque ali se dava a "alta especialização" 21 , o lugar de pesquisa por excelência, que a caracterizaria até nossos dias. Com isto, o historiador da filosofia medieval sinaliza para a força que a Escolástica impõe à comunidade intelectual europeia ocidental, sintetizando, de forma brilhante com estudos da linguagem (gramática, retórica, dialética), fé e razão. ${ }^{22}$ Sob esse aspecto, Cambi analisa o currículo da Escolástica enquanto releitura da paidéia socrática. $\mathrm{O}$ autor sugere que podemos entender este conteúdo no sentido de uma reedição da Antiguidade Clássica transformada em uma "paidéia cristã" ou "cristianizada". ${ }^{23}$ Nesse sentido, a orientação do método da Escolástica reedita a proposta da Antiguidade Clássica de um ensino em torno de sete artes (lógica, gramática, retórica, aritmética, música, geometria e astronomia) distribuídas curricularmente em estudos da linguagem, o Trivium e estudos da matéria, o Quadrivium. ${ }^{24}$

Neste cenário, a Escolástica se destacou como estruturante do perfil que predominaria nas universidades através de seu método de ensino constituído de lectio, meditatio, glossa, quaestio, disputatio. Este rol de procedimentos compunha a rotina do ambiente acadêmico. Dito de outro modo, temos um encontro entre instituição e autoridade, tal como referimos anteriormente e que 
se coadunam para uma cultura sapiente. Ou ainda, como bem destaca Le Goff “[...] às leis da imitação a escolástica uniu as leis da razão, às prescrições da autoridade, os argumentos da ciência". ${ }^{25}$

Segundo apresenta Xavier, desdobramentos da tradição helenística e romana alcançam os tempos medievais através de figuras como Varrão, Cassiodoro, Agostinho, Boécio. Seguindo esta orientação, o intelectual escolástico persegue a "razão iluminada pela fé". ${ }^{26}$ Nesse sentido, evidencia-se o caráter nada nebuloso desta época escolástica na qual a razão é tomada como elemento vigoroso na elaboração do horizonte teológico e a filosofia é uma ferramenta fundamental porque é lugar de excelência da linguagem. Parecenos então que o agon grego clássico expresso por meio da força da persuasão, o peith $\grave{o}^{27}$ estaria transmutado e as quaestiones disputatae fundavam um novo paradigma envolvendo intimamente fé e razão, por meio da palavra (daí a importância dos estudos da linguagem, o Trivium), no qual a teologia emerge como ápice do conhecimento humano institucionalizado. Esta parece ser a função do intelecto posto no homem por Deus ${ }^{28}$ : desenvolver racionalmente vale dizer, através de argumentos lógicos, a fé: consagrá-la, enfim. Sob orientação desta dinâmica, a atividade racional, humana, eleva-se ao divino (ou ao inteligível, se fôssemos rastrear o influxo platônico e neoplatônico, de matiz oriental, dado através da translatio a qual se refere De Libera) e a fé adquire uma envergadura para além da imperfeição do senso comum. Assim, a Escolástica torna-se a grande estrutura que fará a adequação da filosofia à teologia, seguindo a demanda política da época.

Conforme assinala De Libera,

\begin{abstract}
a doutrina escolástica do uno transcendental está, essencialmente, na afirmação de certo tipo de conversibilidade do uno com o ser, conversibilidade que compartilha com os demais transcendentais [Verum e Bonum], e na atribuição ao uno de uma razão (ratio) e de um modo de significação (modus significandi) específicos a atribuição negativa ou a negação da negação, que o distinguem, ao mesmo tempo, do ser, seu objeto, e dos demais "modos" transcendentais do ser $[\ldots] .{ }^{29}$
\end{abstract}

É por meio da articulação afinada entre currículo e método que valorizam o uso da linguagem que a figura do mestre na Escolástica, personagem maior daquela estrutura, interroga sua época sobre a verdade do ensino: somente Deus pode ser chamado de mestre, porque ensina, ou ao homem também é possível atribuir-se essa tarefa? O projeto desta paidéia cristianizada era o de fortalecer a fé por meio da linguagem. Por que unir fé e razão? Como? Qual a importância da educação no projeto teológico e filosófico medieval? 
Essas perguntas colocam em evidência a importância da escolástica como método fundamental para afirmação de uma "revolução formativa" posta em curso com o cristianismo, conforme destaca Franco Cambi. É certo que "no nível espiritual/cultural, foi a consciência cristã que alimentou a identidade da Europa" ${ }^{30}$, diz o historiador da educação. A ideia de educar para a formação desta consciência impulsiona uma pedagogia que foi se constituindo em processo de evangelização apoiada, como vimos principalmente nos estudos da linguagem (Trivium). Ou seja, conjuga-se fé e razão.

\title{
DUAS PERSPECTIVAS DA CONJUGAÇÃO: AGOSTINHO E AQUINO
}

Para Gerd Bornheim, em Santo Agostinho há um "a priori existencial" mergulhado de todo na teologia e que fora dado, em Platão, na forma de uma força de eros movendo o "processo do conhecimento". ${ }^{31}$ Se nos gregos o caminho é de uma metafísica antropológica, nos medievais a metafísica é teológica, pois

\begin{abstract}
no caso de Santo Agostinho, o a priori existencial encontra o seu fundamento na revelação divina; a relação existencial - na qual se manifesta e é conhecida a realidade - deve ser compreendida, em sua última raiz, como uma graça iluminativa doada pelo amor de Deus da fé [...] o conceito de iluminatio é de extrema importância na compreensão do pensamento agostiniano [...] A iluminação possibilita toda verdade, toda episteme. A palavra verdade é usada por Santo Agostinho, de modo precípuo, em relação a Deus: Deus é Verdade [...] O conceito de iluminação implica, pois, dizer que Deus fundamenta e possibilita toda verdade [...] É assim totalmente pacífico que só o imutável, o permanente, o necessário, o comum, o estável se presta à ciência, a uma ciência que encontra o seu fundamento e a sua possibilidade em Deus [...] A ação iluminadora de Deus é antes de mais nada uma força vivificante, uma luz que dá vida [...] O que torna possível toda iluminação, o que a fundamenta, é o Verbo, e pela sua encarnação não se verifica apenas a iluminação do conhecimento humano ou de qualquer outro fenômeno particular, mas de todo o real. ${ }^{32}$
\end{abstract}

Nos capítulos I e XIV, d'O Mestre, Santo Agostinho, em conversa com Adeodato, apresenta as ideias do ensino e rememorar, assim como o mestre e a consciência, respectivamente. A figura do Mestre é uma e só uma: Deus. Ao que chama professor dirige a tarefa de apresentar palavras e sinais, incitando o 
homem a se voltar a Deus para aprender (para tanto vai à autoridade da Bíblia e encontra as palavras de Mateus (23, 8-10) que dizem: "não chamemos mestre a ninguém na terra, pois que o único Mestre de todos nós está nos Céus"). Em Santo Agostinho, o aspecto racional da pedagogia cristã não aparece como aparecerá na escolástica tomista. $\mathrm{O}$ autor sinaliza uma experiência bem mais contemplativa $^{33}$ que propriamente ativa em relação à descoberta da verdade que é transcendente porque se origina em Deus e não no intelecto que é apenas um motor para acioná-la. Toda a formação do homem converge no propósito de um crescimento moral que o leva a Deus. Nesse sentido, o projeto cristão agostiniano é o caminho do homem em direção a civitas Dei e a pedagogia se traduz no exercício da fé.

Oito séculos mais tarde, Tomás de Aquino (1225-1274) reedita a figura do mestre, à luz das novas demandas da história. Uma tentativa de resposta ao "como?" do aprender é dada na atualização da figura do mestre. No que se refere às questões de formação humana, a obra de Aquino emblemática é o De Magistro. Constatamos que o texto compõe-se de quatro artigos por meio dos quais o autor desenvolve a questão disputada sobre quem ensina (Deus, os anjos ou o homem), espelhando a vinculação com o Filósofo, sua lógica, para fundamentar a fé cristã. Segundo Alain De Libera,

Extraordinária síntese entre fé e razão, entre teologia e filosofia, a obra de Tomás de Aquino cobre o conjunto dos saberes e dos gêneros literários medievais: comentários de Aristóteles, comentários das Escrituras, questões disputadas, tratados, opúsculos, sermões e, sobretudo, duas "sumas", uma filosófica - a Summa contra Gentiles (redigida em 1258-1260), outra teológica - a Summa theologiae (composta em 1267-1273), que, cada uma em seu gênero, constituem o auge do que foi denominado o "aristotelismo cristão". Adepto da abertura à filosofia, Tomás é também o principal responsável pela abertura à teologia grega. Para elaborar sua Catena aurea, compêndio de textos patrísticos destinados a alimentar sua obra teórica, faz traduzir do grego um número sem precedente de textos dos Padres gregos. ${ }^{34}$

Não bastasse o conjunto da obra mesma, reunindo o veio filosófico e teológico, ainda teríamos o argumento do desenrolar dos estudos da linguagem (Trivium) como ferramenta estruturante do horizonte tomista, sinalizando o vínculo ineludível entre fé e razão.

Leitor atento e admirador de Aristóteles, na condição de intérprete, Aquino procura atualizar a palavra do clássico extraindo dela sua universalidade que faz transcender o particular. Com o Filósofo, ele aprendera a importância de se ter em mente a perspectiva do particular que somente se desvela na 
experiência, "assim, se alguém dispõe de teoria sem experiência, e conhece o universal, mas não conhece o particular nele contido, com frequência falhará em seu tratamento, uma vez que é o particular que tem que ser tratado". ${ }^{35}$ Todavia, se valendo da lógica de seu mestre, Aquino infere:

Toda certeza do conhecimento origina-se dos princípios: e, de fato, as conclusões só são conhecidas com certeza quando remetem aos princípios. Daí decorre o fato de que qualquer coisa que é conhecida com certeza dependa da luz interior da razão posta em nós por Deus, com a qual Deus fala em nós, e não um homem que fala exteriormente, a menos que pelo seu ensino mostre a concatenação entre as conclusões e os princípios: mas mesmo neste caso a certeza procede dos princípios nos quais as conclusões se apoiam. ${ }^{36}$

Parece ao intérprete que o autor está sussurrando o que sua época ainda não pode escutar, como prenúncio de um teor humanista que o tempo sopra. Lauand chama atenção para este viés antropológico contido em Aquino:

A antropologia de Tomás - revolucionária para a época afirma o homem em sua totalidade (espiritual, sim, mas de um espírito integrado à matéria) e está em sintonia com uma teologia (também dissonante para a época) que, precisamente para afirmar a dignidade de Deus criador, afirma a dignidade do homem e da criação como um todo: material e espiritual. ${ }^{37}$

E é justamente este caráter antropológico que autoriza um destaque à linguagem, racionalidade e método em Aquino. Ou seja, faz sentido sua orientação filosófica em Aristóteles.

No que respeita à filosofia da educação de Tomás de Aquino, nos encontramos diante de seu escrito De magistro. Em primeiro lugar, trata-se de um texto exemplar no sentido de apresentar ao aluno da disciplina de filosofia da educação e teorias da educação (nas licenciaturas) a estrutura do método da escolástica regido pelo silogismo aristotélico. O texto tem por objetivo apresentar racionalmente a questão que corrobora o fundamento teológico da onisciência de Deus: Quem ensina? Deus ou o homem? Esta pergunta subjaz magistralmente o texto em questão e vai sendo deslindada por meio de uma estrutura lógica composta de um jogo de linguagem compreendido a partir da articulação entre Objeções, Em contrário, Solução e a Resposta às objeções, dialogando, principalmente, com autoridades como as Escrituras, Agostinho, São Paulo, Aristóteles, entre outras.

Em segundo lugar, segundo nossa interpretação, mesmo estando vinculado à rígida estrutura da escolástica, contudo, cabe destacar que em 
Aquino a educação é processo. É movimento, considerando-se o deslocamento da potência ao ato. Mas o teólogo é prudente como sua razão: Deus confere ao homem a potência para conhecer, mas é no ato que esta excelência é levada a termo. Ele atualiza a teoria da potência e ato, absolutamente mundana, pagã, da metafísica aristotélica a partir de seu lugar teológico. Ao homem/professor fica o atributo de "agente extrínseco" do ensino que "[...] deve conduzir o aluno ao conhecimento do que ele ignorava, seguindo o caminho trilhado por alguém que chega por si mesmo à descoberta do que não conhecia". ${ }^{38}$

O professor conduz o aluno ao conhecimento que, por sua vez, não lhe é extrínseco e sim, intrínseco, potência causada no homem por Deus na forma de razões seminais, pois "no aluno, o conhecimento já existia, mas não em ato perfeito, e sim como que em 'razões seminais', no sentido que as percepções universais, inscritas em nós, são como que sementes de todos os conhecimentos posteriores". ${ }^{39} \mathrm{E}$, por isso, ensino é "[...] quando a mente é conduzida a conhecer em ato as consequências particulares que já antes e como que em potência estavam naqueles universais [...]". ${ }^{40}$ Logo, o ensino está diretamente relacionado ao conhecimento. Segundo Aquino,

[...] há duas formas de adquirir conhecimento: de um modo, quando a razão por si mesma atinge o conhecimento que não possuía, o que se chama descoberta; e, de outro, quando recebe ajuda de fora, e este se chama ensino [e, neste ponto, ergue-se a figura do mestre, cuja função é de] conduzir o aluno ao conhecimento do que ele ignorava, seguindo o caminho trilhado por alguém que chega por si mesmo à descoberta do que não conhecia. ${ }^{41}$

Observamos que tanto em Aristóteles como em Aquino a figura do mestre aparece como autoridade dada no conhecimento, seja da teoria como da causa - o mestre é o agente extrínseco que ativa a "razão natural" do aluno (substância em Aristóteles; razões seminais em Aquino). Na tentativa de deslindar a questão sobre o ensino, percebemos que se põem os agentes que instauram a ação, o ensinar. O ensino é quando o professor mostra ao aluno os princípios universais que este detém enquanto "luz da razão", posta, nele, por Deus. O ensino compreende o sentido de uma vida contemplativa no que se refere ao pensamento abstrato que o professor possui, mas também impulsiona a vida ativa como momento que lhe procede.

Sobre isto, nos diz:

A visão [contemplativa] do professor é o princípio do ensino, mas o próprio ensino consiste mais na transfusão do conhecimento das coisas vistas do que em sua visão. Daí que a visão do professor pertença mais à contemplação do 
que à ação [...] Ora, a vida contemplativa é o princípio da ativa, enquanto a dirige, como ao contrário: a vida ativa dispõe a contemplativa. ${ }^{42}$

Todavia, a pergunta pelo que é ensinar implica também na compreensão do ato, ou seja, um estar dentro dele para traduzir o que ali se desenrola. Parece que este foi o movimento de Aquino. No interior de um sentido do ensino ele percebe que o mesmo se completa somente quando se dá o instante da descoberta. Aquino afirma que o ensino é um processo no qual estão implicadas as figuras do professor e do aluno.

No texto do século XIII, Aquino analisa o processo pelo qual o aluno aprende nos oferecendo o elemento da descoberta como o momento individual do processo de aprendizagem. As figuras do mestre e do discípulo articulam o télos do ensino da época: consagrar a fé cristã por meio do pensamento racional; tornar mestre o discípulo que advogará por esta fé. A destinação da figura do discípulo é a fundação de seu lugar no mundo, a mestria, e a descoberta é ato, ação própria, e, por que não dizer dramática (no sentido grego do termo $\left.d_{r a n}\right)^{43}$ na qual o discípulo se vê sozinho e responsável pelo que se põe diante de si. Sendo assim, o momento da descoberta, enquanto algo particular e intransferível, também funda no processo do conhecimento uma indispensável solidão. Somente a partir daí será possível projetar-se na vida contemplativa. Quem pode dizer não se tratar de uma poiesis ( $\pi$ oté $\omega)$ ? Este é um ponto que aproxima o indivíduo da época medieval aos tempos subsequentes, os modernos, não no que respeita à transformação de uma poiesis ( $\pi$ oté $\omega$ ) em mera técnica (o que nos levaria à outra conversa), mas naquilo que lhes será mais caro: a própria ideia de indivíduo como algo que não poderia dissociar-se do particular, dado na forma da subjetividade (já posta desde Agostinho, mas que não tratamos no momento) pré-anunciando uma tensão ontológica cara aos tempos ulteriores.

\section{A QUESTÃO NO BRASIL: UMA CONSIDERAÇÃO}

Bittar, Lauand e Lima Vaz ${ }^{44}$ apontam para os elementos de modernidade presentes no horizonte tomista. Mas, contraditoriamente, tal modernidade não se efetiva no tratamento da escolástica com a fundação das primeiras formas de educação escolar no Brasil e "no caso dos sermões luso-brasileiros dos séculos XVI, XVII e XVIII, o público não tem nenhuma autonomia crítica" ${ }^{45}$ Como sabemos, o comprometimento com a estrutura colonial em curso engessa a atuação jesuíta que se vê atravessada pelos desígnios da metrópole portuguesa. No Brasil colônia, as escolas de primeiras letras eram conduzidas pela mão dos jesuítas para um projeto que visava à "civilização pela palavra" 46 nos marcos das referências da civilização europeia e tendo por base a formação escolástica do jesuíta. 
De acordo com o estudo de João Adolfo Hansen, a presença jesuíta no Brasil teve por finalidade primeira desencadear um processo civilizatório sobre a população nativa indígena por meio da palavra, respeitando a tradição oral que vinha desde os apóstolos, pois "os jesuítas tinham optado por um humanismo de cultura e de formação, opondo-se nitidamente ao humanismo de erudição". ${ }^{47}$ Devemos considerar a própria primazia da oralidade presente daquela tradição formativa, tal como apresenta o autor. Nesse sentido, civilizar por meio da palavra respeitava

[...] à divulgação católica da Retórica antiga em duas frentes: de um lado, o ensino específico das técnicas e, ainda, das artes e das letras me geral segundo o modelo generalizado da Retórica aristotélica e das suas versões latinas, nos colégios jesuíticos; de outro, o uso particular de seus preceitos, estilos e erudição pelos pregadores nas variadíssimas circunstâncias do magistério da fé. ${ }^{48}$

Assim,

nos séculos XVI e XVII, nas missões jesuíticas do Brasil e do Maranhão e Grão Pará, a iniciativa de fazer da pregação oral o instrumento privilegiado de divulgação da Palavra divina pressupunha que a luz natural da Graça inata ilumina a mente dos gentios, objeto da catequese, tornando-os predispostos à conversão [...] dada à inconstância da alma dos selvagens brasileiros, a catequese deve seguir o modelo tradicional ou oral dos bons exemplos e das boas obras do ferreiro e não propriamente o da palavra escrita do humanista. ${ }^{49}$

Além disso, o paradigma europeu de civilização impunha um entendimento de homem civilizado como sendo aquele moldado para a demanda social e cultural predominante na Europa ocidental aplicado aos alunos na colônia. Nesse caso, incivilizado seria aquele ser que não se enquadrasse territorial e simbolicamente nos referenciais da vida europeia. ${ }^{50}$ Todavia, há que se dizer que tal ideia de educação para a civilidade não considerava a perspectiva vigente na Europa de uma formação para a autonomia de pensamento. $\mathrm{O}$ estudo de Leonel Franca apresenta detalhadamente a ideia do que era o Ratio Studiorum: um currículo para um curso de formação humanista dos jesuítas. ${ }^{51}$ Com base naquela formação, os jesuítas emolduraram um processo civilizatório, de conversão dos gentios, no Brasil colonial e suas primeiras atuações em terras além-mar. 


\section{CONSIDERAÇÕES FINAIS}

De modo abrangente vimos que a intencionalidade formativa na educação medieval do Ocidente esteve marcada pela formação de consciências. Em Santo Agostinho, exemplo da Patrística, esta formação apresenta um caráter bem mais voltado ao suporte da fé. Com Tomás de Aquino, representante de escolástica, o horizonte formativo se atualiza com base na orientação da lógica aristotélica marcando a junção entre filosofia e teologia, razão e fé. Além disso, vimos que a pergunta pelo sentido do ensinar traz à cena um télos para a educação assim como a relação de dupla face, dialética, entre quem ensina quem aprende e o que é aprendido (o conhecimento). A pergunta também aponta certa antecipação em Aquino de uma perspectiva de ensino que, segundo nossa interpretação, ultrapassa a sua época.

De modo específico esta possibilidade interpretativa recai sobre o sentido que o filósofo atribui ao momento da descoberta, como algo genuinamente novo tanto para o aluno, no processo do ensino, quanto para o horizonte histórico do filósofo. Na solução que o escolástico apresenta para a questão está patente a diferença entre ensino e descoberta, mas não se expressa incongruência entre ambos. Ao contrário, constituem elementos distintos de um mesmo ato. $\mathrm{O}$ ensino pede o agente extrínseco, o professor, enquanto a descoberta é da ordem de uma vivência do aluno, acentuando a importância do elemento particular em negociação de sentido com o universal. Parecenos, então, que a descoberta, enquanto sucedâneo e complementar do ensino, é alçada à categoria de excelência dele mesmo. Encontramos uma dialética entre descoberta e ensino que se expressa no acontecimento do ato, quando o professor ativa a razão natural do aluno: como vimos, ele é seu condutor.

Com Aquino a potência do conhecimento demanda o ato, a experiência mesma que se estrutura a partir da relação mestre-discípulo. Perguntamo-nos se haveria aí um viés antropológico, porque torna imprescindível a relação entre ambos (e, mais ainda, a especificidade de cada uma das figuras que a compõe), avançando sobre os limites do teocentrismo escolástico? Como interpreta Lauand acerca do teor antropológico do pensamento de Aquino, inferimos um sentido fortemente clássico à obra tendo em vista seu potencial de abrir-se, ou deixar sementes, para a posteridade justamente por não esconder o elemento comum da humanidade, razão pela qual seu uso na filosofia da educação orientada no diálogo com a história ainda tem legitimidade. Nesse sentido é sob o signo de uma antropologia que entendemos a perspectiva filosófico-educacional de Aquino, pois ali encontramos uma agonística dada nos usos da linguagem.

Também visualizamos a educação enquanto movimento, sendo ato; um deslocamento de um estado de coisas a outro, cuja presença do professor é fundamental para desencadear tal movimento (fundamental tanto quanto a 
presença do aluno). Percebemos que as palavras clássicas contêm a potência de sua própria atualização hermenêutica. É justamente através da atualização hermenêutica que fazemos da análise do filósofo medieval sobre este momento próprio do aprender, que é a descoberta, que encontramos algo caro ao espírito filosófico nos levando à questão do ensino hoje. Todavia, desde um horizonte hermenêutico a partir do qual nos situamos para interpelar a obra em questão, também nos perguntamos sobre as condições históricas que possibilitaram ao homem a envergadura de tal obra: algo que nos parece ter sido desenvolvido aqui por meio de uma íntima relação entre filosofia e história.

A perspectiva da filosofia da educação de Tomás de Aquino traz à luz a relação professor-aluno, fundante da educação, como sendo algo que ultrapassa seu tempo pré-anunciando o futuro, a modernidade, seja por aquele sentido de movimento que confere à educação, seja pelo destaque, inusitado e novo, que dá ao elemento da descoberta no ensino, inaugurando a importância do particular no processo do ensino, mesmo sob efeitos da estrutura escolástica no que concerne ao seu método e currículo. Uma pista para o entendimento do presente que se debruça sobre seu passado.

\section{NOTAS}

1 Este texto é furto de estudos e pesquisa desenvolvidos em 2012 e 2013 no curso de Pedagogia da UFSC, na disciplina optativa "Leituras histórico-filosóficas da educação no Brasil colonial" (EED 7148) e no projeto de extensão "A perspectiva da filosofia da educação de Tomás de Aquino", respectivamente, bem como participação no I Colóquio Internacional de Filosofia Medieval UNUM VERUM BONUM, na Universidade de Lisboa, também em 2013.

${ }^{2}$ BLOCH, Marc. A sociedade feudal. Tradução de Emanuel Lourenço Godinho. Lisboa: Edições 70, 1982; CAMBI, Franco. História da pedagogia. Tradução de Álvaro Lorencini. São Paulo: Fundação Editora da UNESP (FEU), 1999; HUIZINGA, Johan. O outono da Idade Média. Tradução de Francis Petra Janssen. São Paulo: Cosac Naify, 2010.

${ }^{3}$ SILVEIRA, Aline Dias da. Cristãos, muçulmanos e judeus na medievalística alemã: "Para um novo conceito de Idade Média". AEDOS, Porto Alegre, v. 2, n. 2, 2009. Disponível em: $<$ http://seer.ufrgs.br/aedos/article/view/9865/5724\#edn1>. Acesso em: 02 fev. 2014.

${ }^{4}$ HUIZINGA, op. cit., p. 12.

${ }^{5}$ CAMBI, op. cit., p. 143.

${ }^{6}$ GADAMER, Hans-Georg. Verdade e método. Traços fundamentais de uma hermenêutica filosófica. Tradução de Flávio Paulo Meurer. Petrópolis: Vozes, 1997.

${ }^{7}$ ARISTÓTELES. Metafísica. Tradução de Edson Bini. Bauru/SP: Edipro, 2006.

${ }^{8}$ CAMBI, op. cit., p. 146.

${ }^{9}$ Ibidem, p. 145-146. Destaque do autor.

${ }^{10}$ BEAUNE, Colette. Escola, a escada para a ascensão social. Tradução de Alexandre Massella. História Viva, São Paulo, ano I, n. 5, p. 49, mar. 2004. 
${ }^{11}$ Além deste mapeamento, a autora também destaca a importância da escrita que acompanha a ascensão e certa 'popularização' do livro em função dos primeiros tipos móveis usados por Gutemberg. Sobre isto a autora nos diz: "Os dois últimos séculos da Idade Média presenciam a expansão da escrita, tanto em latim como na língua vulgar. O livro, objeto sagrado e longínquo durante a Alta Idade Média, sai do domínio eclesiástico e político para entrar no uso cotidiano." (BEAUNE, op. cit., p. 49).

${ }^{12}$ LE GOFF, Jacques. Os intelectuais na Idade Média. Tradução de Marcos de Castro. Rio de Janeiro: José Olympio, 2003. DE LIBERA, Alain. A filosofia medieval. Tradução de Nicolás Nyimi Campanário e Yvone Maria de Campos Teixeira da Silva. 3. ed. São Paulo: Loyola, 2011.

${ }^{13}$ SILVEIRA, op. cit., s/p.

${ }^{14}$ BITTAR, Eduardo C. B. O aristotelismo e o pensamento árabe: Averróis e a recepção de Aristóteles no mundo medieval. Revista Portuguesa de História do Livro, Lisboa, n. 24, p. 62, 2009. Disponível em: <http://www.scielo.gpeari.mctes.pt/scielo.php?script=sci_arttext\& pid=S0874-13362009000200004>. Acesso em: 02 fev. 2014.

${ }^{15}$ DE LIBERA, op. cit., p. 17.

${ }^{16}$ HUIZINGA, op. cit., p. 12.

${ }^{17}$ GOMBRICH, Ernst. A história da arte. Tradução de Álvaro Cabral. Rio de Janeiro: LTC, 1999.

${ }^{18}$ LE GOFF, Jacques. A catedral. In: LE GOFF, Jacques. Heróis e maravilhas da Idade Média. Tradução de Stephania Matousek. 2. ed. Petrópolis: Vozes, 2011. p. 41-55.

${ }^{19}$ MARCONDES, Danilo. Textos básicos de filosofia: dos pré-socráticos a Wittgenstein. Rio de Janeiro: Jorge Zahar, 2000; STORK, Alfredo. Filosofia medieval. Rio de Janeiro: Jorge Zahar, 2003; XAVIER, Maria Leonor. Questões de filosofia na Idade Média. Lisboa: Edições Colibri, 2007.

${ }^{20}$ MARCONDES, op. cit., p. 124.

${ }^{21}$ DE LIBERA, op. cit., p. 368.

${ }^{22}$ Ibidem, p. 405.

${ }^{23}$ CAMBI, op. cit., p. 150.

${ }^{24}$ CAMBI, op. cit.; FRANCA, Leonel. O método pedagógico dos jesuitas. Rio de janeiro: Agir, 1952; JAEGER, Werner. Paidéia: a formação do homem grego. Tradução de Artur M. Parreira. São Paulo: Martins Fontes, 1986; XAVIER, op. cit.

${ }^{25}$ LE GOFF, 2003, op. cit., p. 119.

${ }^{26}$ XAVIER, op. cit., p. 35.

${ }^{27}$ VERNANT, Jean-Pierre. As origens do pensamento grego. Tradução de Ísis Borges B. da Fonseca. São Paulo: DIFEL, 1986; JAEGER, op. cit., p. 254-255.

${ }^{28}$ AQUINO, Tomás. Sobre o ensino (De magistro). In: LAUAND, Luiz Jean (Org.). Tomás de Aquino. Sobre o ensino (De magistro). Os sete pecados capitais. Tradução de Luiz Jean Lauand. São Paulo: Martins Fontes, 2004. p. 37-38.

${ }^{29}$ DE LIBERA, op. cit., p. 379.

${ }^{30}$ CAMBI, op. cit., p. 145. Entendemos que a questão entre fé e razão é bem mais atinente, porque marcante, à Baixa Idade Média, com o modelo formativo da escolástica. De modo amplo, a filosofia medieval cristã foi desenvolvendo-se desde a Alta Idade Média (V ao X), 
com a denominada 'Patrística' (II-V), de orientação predominantemente neoplatônica, a exemplo de Agostinho.

${ }^{31}$ BORNHEIM, Gerd. Metafisica e finitude. São Paulo: Perspectiva, 2001. p. 39-40. Cabe sublinhar: não se trata, como esclarece Bornheim, de um inatismo aos moldes modernos (não é algo constituinte do humano enquanto elemento biológico, por ex.), mas sim de uma doação da luz da razão feita por Deus ao homem.

${ }^{32}$ Ibidem, p. 44.

${ }^{33}$ Diz Santo Agostinho: "Não saias, volta para dentro de ti mesmo; a verdade mora dentro do homem." (Cf. CAMBI, op. cit., p. 136).

${ }^{34}$ DE LIBERA, op. cit., p. 405.

${ }^{35}$ ARISTÓTELES, op. cit., p. 44.

${ }^{36}$ AQUINO, op. cit., p. 37.

${ }^{37}$ LAUAND, op. cit., p. 6.

${ }^{38}$ AQUINO, op. cit., 32.

${ }^{39}$ Ibidem, p. 34-35.

${ }^{40}$ Ibidem, p. 31.

${ }^{41}$ Ibidem, p. 32.

${ }^{42}$ Ibidem, p. 62.

${ }^{43}$ ARENDT, Hannah. La condición humana. Tradução de Ramón Gil Novales. Barcelona: Paidós, 2005.

${ }^{44}$ LIMA VAZ, Henrique C. de. Raizes da modernidade. São Paulo: Loyola, 2002.

${ }^{45}$ HANSEN, João Adolfo. A civilização pela palavra. In: TEIXEIRA, Eliane Marta; FARIA FILHO, Luciano Mendes de; VEIGA, Cynthia Greive (Orgs.). 500 anos de Educação no Brasil. Belo Horizonte: Autêntica, 2000. p. 35.

${ }^{46}$ HANSEN, op. cit., p. 19-41.

${ }^{47}$ Ibidem, p. 29.

${ }^{48}$ Ibidem, p. 31.

${ }^{49}$ Ibidem, p. 21-22.

${ }^{50}$ Conforme o estudo de ELIAS, Norbert. O processo civilizador. Tradução de Ruy Jungmann. Rio de Janeiro: Zahar, 2011.

${ }^{51}$ FRANCA, op.cit.

Artigo recebido em agosto de 2013. Aceito em dezembro de 2013. 